\title{
Application Of NANDA, NIC, NOC Diagnosis: Acute Pain In Improving Quality Of Nursing Documentation
}

\author{
Nikodimus Margo Rinenggantyas, M. Rofii, Luky Dwiantoro \\ Diponegoro University Semarang, Indonesia \\ Corresponding author: nuningniko@gmail.com
}

\begin{abstract}
Background: The diagnosis of pain documented in the nursing care process still needs to be evaluated. The reason is because there is still diversity in formulating the problem due to diverse nursing education, nurse knowledge, and even differences in reference standards used.

Purpose: This study aimed to find out the application of diagnoses of nanda, nic, noc in improving the quality of nursing documentation.

Methods: This research method uses research design using descriptive analytics. The population in this study were 150 nurses in the inpatient hospital room of H.L Manambai Abdulkadir. The study sample was 73 nurses. The variable of this study is the application of diagnoses nanda, nic, noc in improving the quality of nursing documentation. Research instruments using questionnaires and statistical tests using frequency distribution.

Results: The results show that the majority of nurse respondents had a female sex of $73 \%$, and male sex numbered $27 \%$. Based on the results of research that has been done, it was found that the majority of nurse respondents had an age of 31-40 years which was $41 \%$, and those aged 20-30 years amounted to $32 \%$ and those aged $>40$ years amounted to $27 \%$. Based on the results of research that has been done, it was found that the majority of nurse respondents had the Application of NANDA, NIC, NOC Diagnosis in improving the Quality of Nursing Documentation by $55 \%$ and less by $45 \%$. application of NANDA, NIC, NOC diagnoses in improving the quality of nursing documentation is good and the need for regular training to maintain it.
\end{abstract}

Conclusion: From the research concluded that the use of diagnosis can improve the quality of nursing documentation

Keywords: Nursing Diagnosis, Nursing Documentation, Nurses 


\section{BACKGROUND}

The diagnosis of pain documented in the nursing care process still needs to be evaluated. The reason is because there is still diversity in formulating the problem due to diverse nursing education, nurse knowledge, and even differences in reference standards used. The diversity of pain nursing diagnoses indirectly affects the completeness of nursing documentation and the quality of nursing documentation (Sugiyono, 2011) The quality of nursing documentation is considered to be quality if it is complete, integrated, systematically arranged and follows the rules of the existing rules, because records of nursing documentation are incomplete and not following the rules of documentation will cause nurses easily sued legally if it is not according to procedure.

The Ministry of Health of the Republic of Indonesia in 2014 showed that completeness of completing nursing care documentation in the hospital was still lacking, namely the results of the study were only $16 \%$, determined $77 \%$ of diagnoses, and made plans $<20 \%$ (Arikunto, 2010). Completeness of filling in the documentation of nursing care obtained results an average of $69.65 \%$, namely assessment of $70.92 \%$, diagnosis formula $66.65 \%$, planning or intervention $71.73 \%$, action or implementation $84.90 \%$, evaluation of actions $31.30 \%$, and nursing records 92, 40\% (Prastanti, 2012). The results of research conducted by Ulum and Wulandari show that the completeness of nursing documentation is $63.7 \%$, Of course this will have an impact on the quality of nursing service quality, which is reportedly not yet running nationally at only as large as $53.8 \%$ (Effendi, 2009) Whereas the standard applied by the Ministry of Health of the Republic of Indonesia is $80 \%$ (Arikunto, 2009)

The impact arising from diverse and incomplete documentation is that nursing care is not optimal, communication is not one-way and there is a risk of patient complaints in the event of an unwanted problem. This affects the quality of nursing services (Mubarak, 2009).

Efforts to improve the quality of documentation of nursing diagnoses have been carried out by means of socializing guidelines and operational standard procedures in the documentation of nursing care, especially in lifting diagnoses. The guidelines for nursing diagnoses so far refer to the North American Nursing Diagnosis Association (NANDA), Nursing Interventions Classification (NIC), and Nursing Outcomes Classification (NOC) however, not all nurses know how to use and write diagnoses based on NANDA rules so that it affects the diagnosis decisions that are enforced by nurses who influence in the selection of interventions and outcomes of nursing care that will be given to patients (Muninjaya, 2011) Factors that cause this are different nurses knowledge and education (Sugiyono, 2011). Writing acute pain diagnosis based on NANDA rules helps nurses immediately understand that the diagnosis is an actual problem that is established based on subjective and objective data that refers to the problem of acute pain nursing and its causes, so nursing interventions in the form of observation of vital signs, deep breathing exercises, pain relaxation distraction techniques, education about self-training relieve pain in a non-pharmacological way, and collaborative analgesic administration is systematically structured and affects the quality of nursing care which can be measured through nursing documentation consisting of standardized diagnoses, interventions and outcomes (Mahyar, 2004).

Based on the researchers' initial study on February 13, 2019 at HL Manambai Abdulkadir Hospital from 20 Medical Record records, in three inpatient rooms namely in the Tulips, Sakura and Flamboyan Rooms, the average value of completing nursing care documentation is around $60 \%$ with details of the formulation $40 \%$ nursing diagnoses, $80 \%$ 


\section{Journal Of Nursing Practice}

http://thejnp.org

ISSN: 2614-3488 (print); 2614-3496 (online)

Vol.3 No.2. April 2020. Page.204-209

nursing care planning, $70 \%$ nursing actions, $80 \%$ evaluation. The hospital itself in carrying out the diagnosis so far does already have guidelines that prioritizes actual problems, such as pain, hyperthermia, nausea, nutritionally less than needed, changes in tissue perfusion, ineffective breath patterns, airway cleansing, and activity intolerance but, based on observation appointment of this diagnosis is not in accordance with the rules of PES (problems, etiology, and symptoms) contained in the NANDA diagnosis. In fact, internationally the nursing diagnoses of NANDA, NIC, and NOC have been considered important as a reference in formulating nursing diagnoses (Muhith, 2017). In addition, interventions and outcomes as part of the nursing process have also been applied in various hospitals.

The problem of pain itself in documenting nursing diagnoses is only documented by the diagnosis of pain, whereas if pain is an actual problem then the correct rules according to the NANDA NIC guidelines are acute pain or chronic pain associated with biological injury agents or physical injury agents characterized by verbal responses and observations nurse. From the results of interviews with the head of the room, the quality team about implementing nursing care documentation, it was found that the documentation process was still experiencing many obstacles, one of which was due to different levels of education and different nurses' knowledge. The nurse said that it was indeed important to equate perceptions in raising pain issues in nursing care documentation based on the NIC NANDA NOC Diagnosis. Therefore, researchers are interested in examining the effect of applying NANDA NIC NOC diagnostics to the quality of nursing care documentation.

\section{METHODS}

This research method uses research design using descriptive analytics. The population in this study were 150 nurses in the inpatient hospital room. H.L Manambai Abdulkadir. The study sample was 73 nurses. The variables of this study are the application of diagnoses NANDA, NIC, NOC in improving the quality of nursing documentation. Research instruments using questionnaires and statistical tests using frequency distribution.

\section{RESULTS}

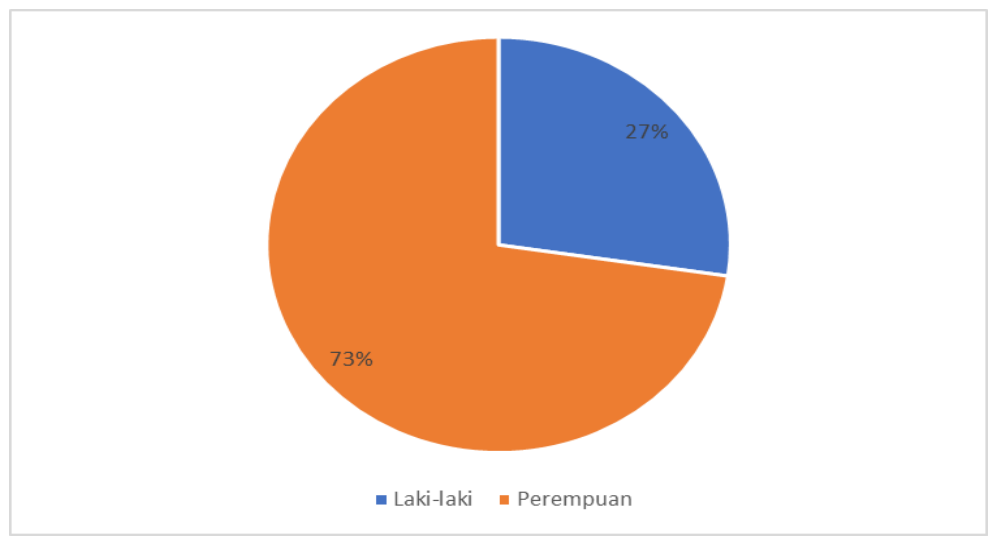

Figure 1 Distribution frequencies of respondent by sex 


\section{Journal Of Nursing Practice}

http://thejnp.org

ISSN: 2614-3488 (print); 2614-3496 (online)

Vol.3 No.2. April 2020. Page.204-209

Based on the results of research that has been done, it was found that the majority of nurse respondents had a female sex of $73 \%$, and male sex numbered $27 \%$.

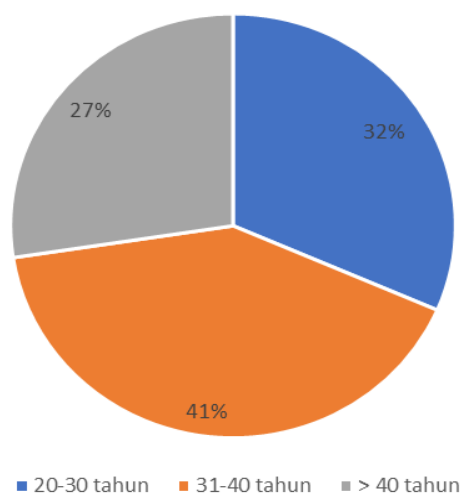

Figure 2 distribution Frequency of respondents based on age

Based on the results of research that has been done, it was found that the majority of nurse respondents had an age of 31-40 years which was $41 \%$, and those aged 20-30 years totaling $32 \%$ and those aged $>40$ years totaling $27 \%$.

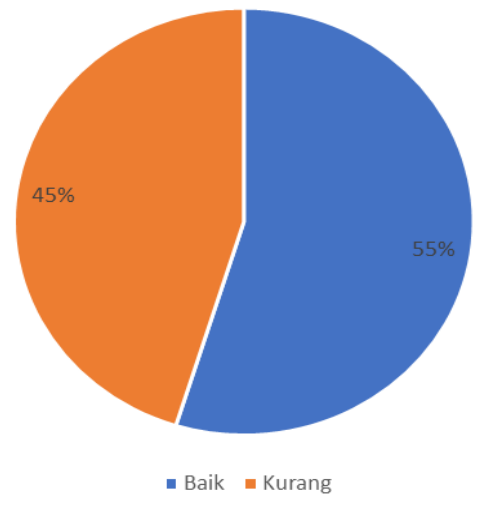

Figure 2 Distribution Frequency of respondents based on the application of the diagnosis of NANDA, NIC, NOC in improving the quality of nursing documentation

Based on the results of research that has been done, it was found that the majority of nurse respondents had the Application of Diagnosis of NANDA, NIC, NOC in Improving the Quality of Nursing Documentation by $55 \%$ and less by $45 \%$.

\section{DISCUSSION}

Based on the results of research that has been done, it was found that the majority of nurse respondents had a female sex of $73 \%$, and male sex numbered $27 \%$. Based on the results of research that has been done, it was found that the majority of nurse respondents had an age of 31-40 years which was $41 \%$, and those aged $20-30$ years amounted to $32 \%$ and those aged $>40$ years amounted to $27 \%$. Based on the results of research that has been done, it was found that the majority of nurse respondents had the Application of NANDA, NIC, NOC Diagnosis in Improving the Quality of Nursing Documentation by $55 \%$ and less by $45 \%$.

Nursing care is a whole set of nursing processes that are provided to patients on an ongoing basis with nursing tips that begin from the assessment to the evaluation in an 


\section{Journal Of Nursing Practice}

http://thejnp.org

ISSN: 2614-3488 (print); 2614-3496 (online)

Vol.3 No.2. April 2020. Page.204-209

effort to improve or maintain optimal health (Potter, 2016). The nurse collects data on the client's health status in a systematic, comprehensive, accurate, concise and continuous manner. Nursing assessment is an important aspect in the nursing process that aims to establish basic data about the client's health level that is used to formulate client problems and action plans. (Ball, 2005)

The Ministry of Health of the Republic of Indonesia establishes criteria or indicators for the quality of nursing care documentation, that is quality documentation if the documented data is accurate, complete, and thorough, based on facts, logical, readable, organized, up-to-date, and maintains confidentiality according to standards (Maatilu, 2014)

Documentation is a communication tool between health professions, therefore data written in nursing documentation must be clear and require accuracy. This aims to avoid the occurrence of misperceptions between health teams that will have an impact on patients. To avoid these incidents, nurses must record every change in the patient, record the services provided and the results of observations made, record on the sheet provided and include the nurse's name and signature (Maatilu, 2014).

Accurately means that what is documented uses true and valid values so that it can be maintained. Proper and accurate execution in the records must reflect the nurse's activities that have been carried out. Documentation must be based on facts. According to Enggland information about patients and care must be based on facts. Records must contain descriptive and objective information about what nurses see, hear and feel. Objective descriptive is the result of direct observation and measurement, so it will not cause misinterpretation (Maatilu, 2014).

Logically interpreted in accordance with the flow of thought, recorded chronologically, including the name and register of each sheet, start writing with capital letters, done with the identity of time (hours, dates, days, months, and years). The writing is clear and can be read by anyone, both between nursing staff and with other professions, written using signs, using abbreviations that are commonly used in nursing documentation (Maatilu, 2014). Organized means to have the appropriate format in each writing at each stage, so that it can communicated among nursing staff and understood together. Up-todate means that the recording is carried out with all current conditions and is not delayed or the data exchange rate must always be up to date. Maintaining confidentiality means that documentation as a medium for maintaining data security is only used for official purposes and is related to the status of the patient or nursing staff concerned. Existing information is documented only for health workers (Maatilu, 2014).

\section{CONCLUSION}

Based on the results of research that has been done, it was found that the majority of nurse respondents had a female sex of $73 \%$, and male sex numbered $27 \%$. Based on the results of research that has been done, it was found that the majority of nurse respondents had an age of 31-40 years which was $41 \%$, and those aged $20-30$ years totaling $32 \%$ and those aged $>40$ years totaling $27 \%$. Based on the results of research that has been done, it was found that the majority of nurse respondents had the Application of Diagnosis of NANDA, NIC, NOC in Improving the Quality of Nursing Documentation by 55\% and less by $45 \%$. 


\section{Journal Of Nursing Practice}

http://thejnp.org

ISSN: 2614-3488 (print); 2614-3496 (online)

Vol.3 No.2. April 2020. Page.204-209

\section{REFERENCES}

Arikunto S. (2010). Prosedur Penelitian. Suatu pendekatan praktek. Edisi revisi. Jakarta: Rineka Cipta.

Ball, M. J. (2005). Nursing Informatics of tomorrow. Healthcare Informatics Online, 2(5).

Dharma, K. K. (2011). Metodologi penelitian keperawatan: Panduan melaksanakan dan menerapkan hasil penelitian. Jakarta Timur: Trans Info Media.

Efendi, F., \& Makhfudli, M. (2009). Keperawatan Kesehatan Komunitas: teori dan praktik dalam keperawatan. Jakarta: Salemba Medika.

Efendy, M. A., \& Purwandari, R. (2012). Perbedaan tingkat kualitas dokumentasi proses keperawatan sebelum dan sesudah penerapan NANDA-I, NIC, dan NOC. Jurnal Keperawatan Soedirman, 7(2), 67-77. http://dx.doi.org/10.20884/1.jks.2012.7.2.358

Hidayat, A. A. (2004). Pengantar konsep dasar keperawatan. Jakarta: EGC.

Maatilu, V., Mulyadi, N., \& Malara, R. (2014). Faktor-Faktor yang Berhubungan dengan Response Time Perawat pada Penanganan Pasien Gawat Darurat di IGD RSUP Prof. Dr. RD Kandou Manado. Jurnal Keperawatan, 2(2).

Mahyar Suara et al. (2010). Konsep dasar keperawatan, Trans Info Media, Jakarta.

Mubarak, W., \& Chayatin, N. (2009). Ilmu Kesehatan Masyarakat; Teori dan Aplikasi. Jakarta: Salemba Medika.

Muhith A. (2017). Pengembangan Model Mutu Asuhan Keperawatan dan MAKP. Yogyakarta: $\mathrm{CV}$ Treeprenuer.

Muhith, A. (2012). Nursalam. Mutu Asuhan Keperawatan Berdasarkan Analisis Kinerja Perawat Dan Kepuasan Perawat Dan Pasien. Jurnal Ners, 7(1), 47-55.

Muninjaya, A. G. (2011). Manajemen mutu pelayanan kesehatan. Jakarta: EGC.

Nursalam. (2014). Manajemen Keperawatan: Aplikasi dalam Praktik Keperawatan Profesional Edisi 4. Jakarta: Salemba Medik.

Potter, P. A., Perry, A. G., Stockert, P., \& Hall, A. (2016). Fundamentals of Nursing-EBook. Elsevier health sciences.

Prastanti, D. W. (2012). Hubungan Kelengkapan Dokumentasi Keperawatan Dengan Mutu Pelayanan Keperawatan Di Ruang Melati RSUD Prof. Margono Soekarjo Purwokerto. (Skripsi, UNIVERSITAS MUHAMMADIYAH PURWOKERTO).

Sugiyono, P. (2011). Metodologi penelitian kuantitatif kualitatif dan R\&D. Alpabeta, Bandung. 